http://doi.org/10.35784/iapgos.930

\title{
NONSTATIONARY HEAT CONDUCTION IN MULTILAYER GLAZING SUBJECTED TO DISTRIBUTED HEAT SOURCES
}

\author{
Natalia Smetankina, Oleksii Postnyi \\ A. Pidgorny Institute for Mechanical Engineering Problems of the National Academy of Sciences of Ukraine
}

Abstract. A method for calculation of nonstationary thermal fields in a multilayer glazing of vehicles under the effect of impulse film heat sources is offered. The glazing is considered as a rectangular multilayer plate made up of isotropic layers with constant thickness. Film heat sources are arranged on layers' interfaces. The heat conduction equation is solved using the Laplace transformation, series expansion and the second expansion theorem. The method offered can be used for designing a safe multilayer glazing under operational and emergency thermal and force loading in vehicles.

Keywords: safe multilayer glazing, nonstationary heat conduction, film heat source

\section{NIESTACJONARNE PRZEWODZENIE CIEPLA W SZYBACH WIELOWARSTWOWYCH NARAŻONYCH NA DZIAŁANIE ROZPROSZONYCH ŹRÓDEŁ CIEPŁA}

\begin{abstract}
Streszczenie. Zaproponowano metodę obliczania niestacjonarnych pól temperaturowych w wielowarstwowych szybach pojazdów pod wpływem impulsowych cienkowarstwowych źródel ciepła. Przeszklenie jest traktowane jako prostokątna wielowarstwowa płyta złożona z izotropowych warstw o stałej grubości. Cienkowarstwowe źródta ciepła znajduja się na granicach warstw. Równanie niestacjonarnego przewodnictwa cieplnego rozwiazuje sie za pomoca rozwinięcia Laplace'a $w$ funkcji czasu, rozkładając funkcje $w$ szeregi $i$ stosujac twierdzenie o drugim rozwinięciu. Zaproponowane podejście może być wykorzystane przy projektowaniu bezpiecznego wielowarstwowego oszklenia pojazdów w warunkach obciażeń termicznych eksploatacyjnych i awaryjnych.
\end{abstract}

Słowa kluczowe: bezpieczne szkła wielowarstwowe, niestacjonarna przewodność cieplna, cienkowarstwowe źródło ciepła

\section{Introduction}

One of the urgent problems in modern technology is the task of reliable determination of the thermal state of structural elements. Its successful solution depends on the reliability and efficiency of the elements of different structures, which often have a heterogeneous structure.

The aircraft's modern heating glass is a complex, large, multilayered structure. Its performance depends primarily on the strength and durability of the glass elements, the optimal parameters of adhesive layers and structural solutions that would provide the necessary heat resistance and durability of the roofing layer under cyclic loading and the action of extreme operating factors.

It should be noted that in the calculation of temperature fields in multilayer structures there are considerable mathematical difficulties. This is due to the presence of layers whose properties are significantly different, and the fulfilment of the conditions of coupling of the layers taking into account the internal heat sources.

\section{Analysis of publications by research topic}

Practical work on the design of protective glazing of vehicles has led to the creation of standards for multilayer safety glasses, which are designed to protect human life, ensure safety and reliability while storing and transporting material.

In modern engineering, the problem of valid identification of the thermal condition of structural components is a topical one. Models and methods of solving heat conduction and thermal elasticity problems are reviewed in [2]. Analysis of the literature has shown that uniform structures are the most investigated ones.

A review of the literature indicates that most publications are devoted to the calculation of structures under steady-state heating [4].

If the temperature field changes slowly with time, one can ignore the inertia terms in motion equations and the coupling term in the heat conduction equation, and consider the thermal elasticity problem as a quasistatic one. The monographs by Melan and Parkus [7], Gatewood [3], and Novatsky [8] have comprehensively developed the theory and solved concrete problems.

The thermal elasticity problem in the quasistatic statement has the greatest practical value. Due to insignificant dynamic effects under common nonstationary heat exchange conditions, one can ignore the coupling of mechanical and thermal energy, and solve the temperature stresses problem in two stages, viz. first solve the heat conduction equation and then determine the field of stresses using the thermal elasticity equation and the temperature distribution found.

For multilayer elements in constructions, heat conduction problems are solved by involving different kinds of hypotheses on temperature distribution over the thickness of the pack of layers. Therefore, the majority of papers use the following numerical computation methods: the finite difference method, the boundary elements method (BEM), and finite elements method (FEM).

Jane and $\mathrm{Wu}[6]$ used the Laplace transform and the finite difference method for solving dynamic and static thermal elasticity problems for multilayer conical shells.

Within the framework of the two-dimensional theory of thermal elasticity, Ishiguro and Tanaka [5] built a model of strain in plate-like constructions for stationary thermal flux conditions. The problem was reduced to solving a system of boundary integral equations discretized by the BEM. The technique described was used for calculating the parameters of the thermal stressed state in anisotropic rectangular plates.

Using the FEM, Oguamanam et al. [9] studied the nonlinear response of a laminated symmetrical orthogonally reinforced cylindrical panel to sudden application of a heat flux. The panel is cantilevered to a hub with limited rotation around the central axis of rotation. The temperature field thickness is constant and changes exponentially with time. The system of nonlinear equations is solved with the Newton-Raphson method jointly with the Newmark integration method.

Verijenko et al. [15], Barut et al. [1] applied the hypothesis on the piecewise-linear temperature distribution over the thickness of the multilayer pack to study stationary temperature fields in multilayer composite shells and rectangular panels in plan. The stress fields were calculated using the FEM.

Analytical methods are mathematically very involved when describing the geometrical parameters of multilayer bodies with a noncanonical configuration; the conditions of layer conjugation with account of inner heat sources, and with presence of layers with significantly differing properties.

Savoia and Reddy [11] investigated stresses in multilayer composite rectangular simply supported plates under uniform heating of the plates' outer surfaces. A polynomial and exponential temperature distribution was specified over the thickness of the pack of layers. The thermal elasticity equations were solved with the Navier method. Ootao and Tanigawa [10] used a similar 
approach for calculating temperature stresses in the layers of a two-layer cylindrical composite simply supported panel.

In the paper [14] a nonstationary thermal conduction problem for layered rectangular plates at a given temperature distribution on the outer and inner surfaces is solved analytically without involving hypotheses about the temperature distribution along the plate thickness.

The unresolved problem is the development of effective methods for investigating the thermal conductivity of multilayer glazing with high parameters of thermal force loading during operational and emergency impacts.

The aim of this work is to develop a method of calculating non-stationary temperature fields in multilayer glazing of aircraft under the influence of pulsed distributed interlayer heat sources.

\section{Solution method}

Consider a multilayer rectangular plate assembled from $I$ isotropic layers of constant thickness $h_{i}, i=1,2, \ldots, I$. The dimensions of the plate in the direction of $X$-axis and $Y$-axis denote $A$ and $B$, respectively. The coordinate $z_{i}$ is counted from the inner surface of each layer, $0 \leq z_{i} \leq h_{i}$. As the coordinate surface, select the front surface of the first layer of the plate, $z_{1}=0$.

We write the heat equation for the $i$-th layer of the plate:

$$
T_{, t}^{i}=a_{i} \Delta T^{i}, i=1,2, \ldots, I, \Delta=\frac{\partial^{2}}{\partial x^{2}}+\frac{\partial^{2}}{\partial y^{2}}+\frac{\partial^{2}}{\partial z_{z_{i}}^{2}}
$$

where $T^{i}=T^{i}\left(x, y, z_{i}, t\right)$ is temperature; $a_{i}=\lambda_{i} /\left(\rho_{i} c_{i}\right)$ is thermal diffusivity, $\lambda_{i}$ is coefficient of thermal conductivity, $\rho_{i}$ is relative density, $c_{i}$ is specific heat of the $i$-th layer material, $t$ is time. We accept zero initial conditions

$$
\left.T^{i}\right|_{t=0}=0, \quad i=1,2, \ldots, I
$$

Zero temperature is maintained on the side surface of the plate

$$
\left.T^{i}\right|_{x=0, x=A}=\left.T^{i}\right|_{y=0, y=B}=0, i=1,2, \ldots, I
$$

On the front surfaces of the plate there is convective heat transfer with the external environment. We write down the boundary conditions

$$
\begin{gathered}
T_{, z_{1}}^{1}-\frac{\alpha_{\text {in }}}{\lambda_{1}} T^{1}=-\frac{\alpha_{\text {in }}}{\lambda_{1}} T_{\text {in }}, z_{1}=0 \\
T_{, z_{I}}^{I}+\frac{\alpha_{\text {out }}}{\lambda_{I}} T^{I}=\frac{\alpha_{\text {out }}}{\lambda_{I}} T_{\text {out }}, z_{I}=h_{I}
\end{gathered}
$$

and conditions for thermal conjugation of layers

$$
\begin{gathered}
T^{i}=T^{i+1}, i=1,2, \ldots, I-1 \\
\lambda_{i} T_{, z_{i}}^{i}=\lambda_{i+1} T_{, z_{i+1}}^{i+1}+q_{S}^{i}, i=1,2, \ldots, I-1
\end{gathered}
$$

where $\alpha_{\text {in }}, \quad \alpha_{\text {out }}, T_{\text {in }}(x, y), \quad T_{\text {out }}(x, y)$ are coefficients of convective heat transfer and ambient temperature on the front surfaces of the plate, respectively; $q_{S}^{i}(x, y)$ are intensities of film heat sources located at the contact boundary of neighboring layers.

After the Laplace transform with respect to the variable $t$, we obtain the operator equation

$$
p T_{i}^{*}=a_{i} \Delta T_{i}^{*}, i=1,2, \ldots, I
$$

where $T_{i}^{*}\left(x, y, z_{i}\right)$ is an image of $T^{i}=T^{i}\left(x, y, z_{i}, t\right)$.

The transformation of the initial (2) and boundary (3), (6) conditions is carried out by simple replacement $T^{i}$ by $T_{i}^{*}$. The boundary conditions (4), (5) and (7) in the image space take the form

$$
T_{1, z_{1}}^{*}-\frac{\alpha_{\text {in }}}{\lambda_{1}} T_{1}^{*}=-\frac{1}{p} \frac{\alpha_{\text {in }}}{\lambda_{1}} T_{\text {in }}, z_{1}=0
$$

$$
\begin{gathered}
T_{I, z_{I}}^{*}+\frac{\alpha_{\text {out }}}{\lambda_{I}} T_{I}^{*}=\frac{\alpha_{\text {out }}}{\lambda_{I}} T_{\text {out }}, \quad z_{I}=h_{I} \\
\lambda_{i} T_{i, z_{i}}^{*}=\lambda_{i+1} T_{i+1, z_{i+1}}^{*}+\frac{1}{p} q_{S}^{i}, i=1,2, \ldots, I-1
\end{gathered}
$$

The solution to operator equation (8) is sought in the form

$$
\begin{gathered}
T_{i}^{*}\left(x, y, z_{i}\right)=T^{*}(x) T^{*}(y) T_{i}^{*}\left(z_{i}\right), \\
\frac{d^{2} T^{*}(x)}{d x^{2}} / T^{*}(x)+\frac{d^{2} T^{*}(y)}{d y^{2}} / T^{*}(y)+\frac{d^{2} T^{*}\left(z_{i}\right)}{d z_{i}^{2}} / T^{*}\left(z_{i}\right)=p / a_{i}
\end{gathered}
$$

which allows us to go to a system of ordinary differential equations

$$
\begin{gathered}
\frac{d^{2} T^{*}(x)}{d x^{2}}=-\alpha_{m}^{2} T^{*}(x), \frac{d^{2} T^{*}(y)}{d y^{2}}=-\beta_{n}^{2} T^{*}(y) \\
\frac{d^{2} T^{*}\left(z_{i}\right)}{d z_{i}^{2}}-\left(p / a_{i}+\alpha_{m}^{2}+\beta_{n}^{2}\right) T^{*}\left(z_{i}\right)=0
\end{gathered}
$$

Solving equations (12) taking into account the boundary conditions (3) on the plate contour, we obtain

$$
T_{m}^{*}(x)=R_{m} \sin \alpha_{m} x, T_{n}^{*}(y)=Q_{n} \sin \beta_{n} y,
$$

where $\alpha_{m}=m \pi / A, \beta_{n}=n \pi / B$.

Therefore, the solution of equation (8) is written in the form of a double series

$$
T_{i}^{*}\left(x, y, z_{i}\right)=\frac{4}{A B} \sum_{m=1}^{\infty} \sum_{n=1}^{\infty} T_{i m n}^{*}\left(z_{i}\right) \sin \alpha_{m} x \sin \beta_{n} y
$$

Functions $T_{\text {in }}(x, y), T_{\text {out }}(x, y)$ and $q_{S}^{i}(x, y)$ also expand to series

$$
\begin{aligned}
T_{\text {in }}(x, y) & =\sum_{m=1}^{\infty} \sum_{n=1}^{\infty} T_{\text {in } m n} \sin \alpha_{m} x \sin \beta_{n} \\
T_{\text {out }}(x, y) & =\sum_{m=1}^{\infty} \sum_{n=1}^{\infty} T_{\text {out } m n} \sin \alpha_{m} x \sin \beta_{n} \\
q_{S}^{i}(x, y) & =\sum_{m=1}^{\infty} \sum_{n=1}^{\infty} q_{S m n}^{i} \sin \alpha_{m} x \sin \beta_{n} y
\end{aligned}
$$

where

$$
\begin{aligned}
& T_{\text {in } m n}=\frac{4}{A B} \int_{0}^{A} \int_{0}^{B} T_{\text {in }}(x, y) \sin \alpha_{m} x \sin \beta_{n} y d x d y, \\
& T_{\text {out } m n}=\frac{4}{A B} \int_{0}^{A} \int_{0}^{B} T_{\text {out }}(x, y) \sin \alpha_{m} x \sin \beta_{n} y d x d y, \\
& q_{S m n}^{i}=\frac{4}{A B} \int_{0}^{A} \int_{0}^{B} q_{S}^{i}(x, y) \sin \alpha_{m} x \sin \beta_{n} y d x d y .
\end{aligned}
$$

The coefficient $T_{i m n}^{*}\left(z_{i}\right)$ is determined by solving the transformed equation (13)

$$
\frac{d^{2} T_{i m n}^{*}\left(z_{i}\right)}{d z_{i}^{2}}+\left(k^{2} / a_{i}-\alpha_{m}^{2}-\beta_{n}^{2}\right) \Gamma_{i m n}^{*}\left(z_{i}\right)=0
$$

where $p=-k^{2}$. The boundary conditions (6), (9)-(11) are also transformed taking into account (15), (16), and the general solution of equation (17) has the form

$$
\begin{gathered}
T_{i m n}^{*}\left(z_{i}\right)=C_{i} \operatorname{ch} \eta_{i} z_{i}+D_{i} \operatorname{sh} \eta_{i} z_{i} \text { if } k^{2} / a_{i}-\alpha_{m}^{2}-\beta_{n}^{2}<0, \\
T_{i m n}^{*}\left(z_{i}\right)=C_{i} \cos \mu_{i} z_{i}+D_{i} \sin \mu_{i} z_{i} \text { if } k^{2} / a_{i}-\alpha_{m}^{2}-\beta_{n}^{2}>0,
\end{gathered}
$$

where $\eta_{i}^{2}=-\left(k^{2} / a_{i}-\alpha_{m}^{2}-\beta_{n}^{2}\right), \mu_{i}^{2}=k^{2} / a_{i}-\alpha_{m}^{2}-\beta_{n}^{2}, i=1,2, \ldots, I$.

The coefficients $C_{i}$ and $D_{i}$ are determined from a system of linear algebraic equations, which is formed from the boundary conditions. After determining the coefficients $C_{i}$ and $D_{i}$, the original of the desired function $T_{i m n}\left(z_{i}, t\right)$ is found by the second decomposition theorem, and the solution of equation (1) has the form

$$
T^{i}\left(x, y, z_{i}, t\right)=\sum_{m=1}^{\infty} \sum_{n=1}^{\infty} T_{i m n}\left(z_{i}, t\right) \sin \alpha_{m} x \sin \beta_{n} y .
$$




\section{Analysis of the numerical results}

Consider heating a five-layer glazing element of the airplane with dimensions $A=0.64 \mathrm{~m}, B=0.32 \mathrm{~m}$ (Fig. 1). Between the first and second layers a film heat source are placed with power $q^{0}=3500 \mathrm{~W} / \mathrm{m}^{2}, q_{S}^{1}(x, y)=q^{0} H(t)$, where $H(t)$ is Heaviside function, $x_{1}=0.07 \mathrm{~m}, \quad x_{2}=0.57 \mathrm{~m}, \quad y_{1}=0 \mathrm{~m}, \quad y_{2}=0.32 \mathrm{~m}$. The layers have the following thermophysical and geometric characteristics:

$$
\begin{aligned}
& \lambda_{i}=1.61 \mathrm{~W} /\left(\mathrm{m} \cdot{ }^{\circ} \mathrm{C}\right), c_{i}=750 \mathrm{~J} /\left(\mathrm{kg} \cdot{ }^{\circ} \mathrm{C}\right), \\
& \rho_{i}=2500 \mathrm{~kg} / \mathrm{m}^{3}(i=1,3,5), \\
& \lambda_{i}=0.17 \mathrm{~W} /\left(\mathrm{m} \cdot{ }^{\circ} \mathrm{C}\right), c_{i}=1500 \mathrm{~J} /\left(\mathrm{kg} \cdot{ }^{\circ} \mathrm{C}\right), \\
& \rho_{i}=1200 \mathrm{~kg} / \mathrm{m}^{3}(i=2,4) ;
\end{aligned}
$$$$
h_{1}=5 \mathrm{~mm}, h_{2}=3 \mathrm{~mm}, h_{3}=15 \mathrm{~mm}, h_{4}=2 \mathrm{~mm}, h_{5}=20 \mathrm{~mm} \text {. }
$$

The coefficients of convective heat transfer on the outer and inner surfaces of the glazing element and the temperature of the external and internal environment are:

$$
\begin{aligned}
& \alpha_{\text {in }}=80 \mathrm{~W} /\left(\mathrm{m}^{2} \cdot{ }^{\circ} \mathrm{C}\right), \alpha_{\text {out }}=25 \mathrm{~W} /\left(\mathrm{m}^{2} \cdot{ }^{\circ} \mathrm{C}\right), \\
& T_{\text {in }}=-20^{\circ} \mathrm{C} \text { and } T_{\text {out }}=20^{\circ} \mathrm{C} .
\end{aligned}
$$

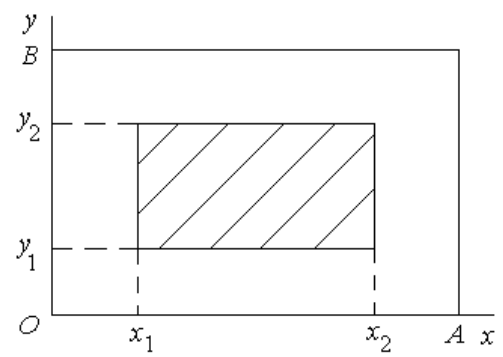

Fig. 1. The design scheme of the glazing element

The composition of the layers and the temperature distributions along the thickness of the glazing element at a point $x=A / 2, y=B / 2$ at time $t=10^{4} \mathrm{~s}$ is shown at Fig. 2. Line 1 is the result of the analytical solution of the problem by the proposed method, line 2 is the result of using development of the sought functions in a series of Legendre polynomials method [12]. Comparative analysis of relations allows making the conclusion about the probability of the obtained results.

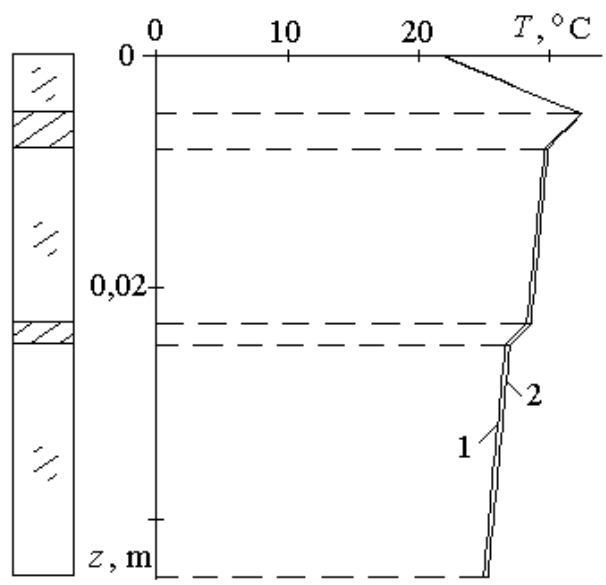

Fig. 2. Temperature distribution through the thickness of the glazing element

The temperature change in the point $x=A / 2, y=B / 2$ on different surfaces of the layers is shown at Fig. 3: line $1-z_{1}=0$, line $2-z_{1}=h_{1}$, line $3-z_{I}=h_{I}$.
The dashed lines in the figure indicate the values of temperatures on the surfaces of the layers, which are solutions of a stationary problem [13]. It can be seen that from the time of the temperature field becomes stationary.

Consider now the thermal condition of a five-layer glazing element of the airplane with dimensions $A=B=0.4 \mathrm{~m}$ containing a heat-generating film with power $q^{0}=3500 \mathrm{~W} / \mathrm{m}^{2}$, $x_{1}=y_{1}=0.15 \mathrm{~m}, x_{2}=y_{2}=0.35 \mathrm{~m}$. As it has been specified above, we arrange the film between the first and the second layers of the element. The thicknesses, the coefficients of convective heat transfer on the outer and inner surfaces of the glazing element and the temperature of the external and internal environment are the same.

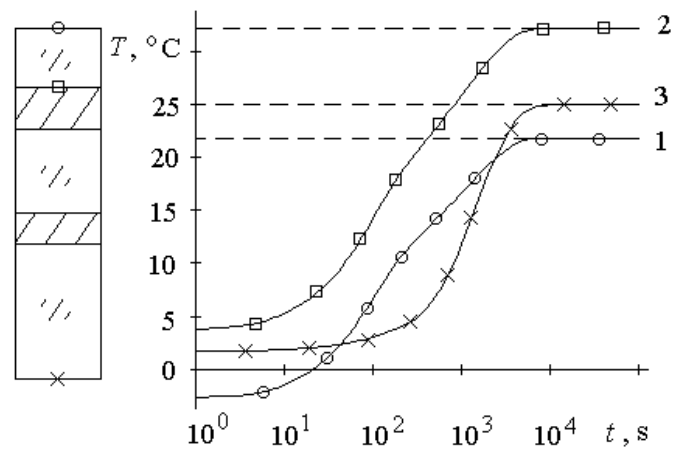

Fig. 3. Temperature changing over time

Fig. 4 shows the temperature distribution through the thickness of the element at different moments of time in the point $x=A / 2, y=B / 2$. The dash-dot line designates the position of the heat-generating film in the package of layers. At $t=1 \mathrm{~s}$ the temperature distribution is non-linear through the thickness of layers, which is appreciable especially in the third and the fifth layers. With time, the temperature distribution in all layers also becomes linear (curve $3, t=10^{3} \mathrm{~s}$ ). A large temperature gradient is observed in layers close to the surface with the heat-generating film. Since $t=5 \cdot 10^{3} \mathrm{~s}$ the temperature field does not practically vary, i.e. it stays steady.

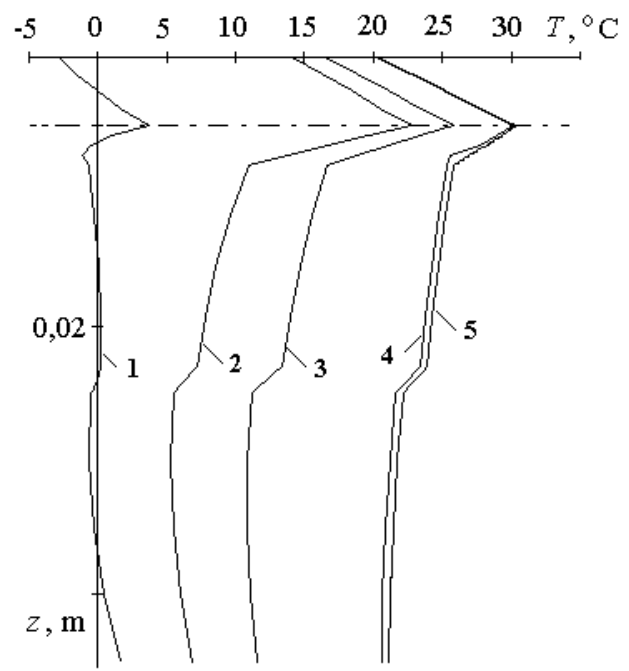

Fig. 4. Distribution of temperature through the thickness of the glazing element at different moments of time: $1-t=1 \mathrm{~s}, 2-t=5 \cdot 10^{2} \mathrm{~s}, 3-t=10^{3} \mathrm{~s}, 4-t=5 \cdot 10^{3} \mathrm{~s}$, $5-t=10^{4} \mathrm{~s}$

Fig. 5 shows a temperature field on the surface with the film heat source at the moment of time $t=5 \cdot 10^{3} \mathrm{~s}$. 


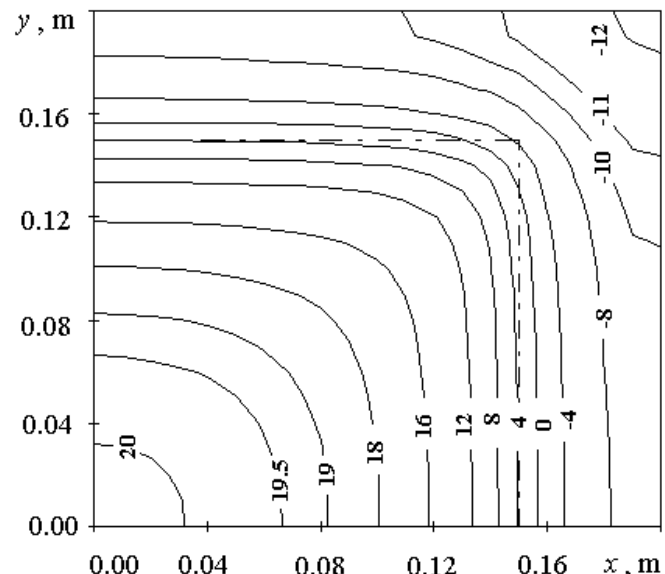

Fig. 5. Temperature field on the surface with the film heat source

\section{Conclusions and prospects for further research}

An analytical method for solution of the non-stationary heat conduction problem in multilayer glazing with an internal heat source is proposed. The multilayer glazing is considered as a rectangular plate made up of isotropic layers with constant thickness. Convective heat transfer occurs on outer surfaces of the plate. The temperature distribution in each layer of the plate is obtained analytically from the heat equation using the Laplace transform. As an example, we solved the nonstationary heat conduction problem for a five-layer glazing element under heating by the film heat source. The comparative analysis of the temperature distribution over the element thickness with the results of other method is carried out.

The solution of such problems has practical importance, as the results of this research can be applied to the analysis of the efficiency of deicing and demisting performances of heating systems for windshields of airplanes and different vehicles.

\section{References}

[1] Barut A., Madenci E., Tessler A.: Non-linear analysis of composite panels unde non-uniform temperature distribution. Int. J. Solids and Struct 37(27)/2000, 3681-3713.

[2] Bielski W.R.: Controllability and stabilization in elasticity, heat conduction an thermoelasticity: Review of recent developments. J. of Global Optimization 17(4)/2000, 353-386

[3] Gatewood B.E.: Thermal stresses. McGraw-Hill, New York 1957.

[4] Goldstein R.J., Ibele W.E., Patankar S.V., et al.: Heat transfer - a review of 2003 literature. Int. J. Heat Mass Transfer 49(3-4)/2006, 451-534.
[5] Ishiguro S., Tanaka M.: Analysis of two-dimensional anisotropic thermoelasticity by boundary element method. Trans. Jap. Soc. Mech. Eng. A 63(613)/1997, 1963-1970.

[6] Jane K.C., Wu Y.H.: A generalized thermoelasticity problem of multilayered conical shells. Int. J. Solids and Structures 41(9-10)/2004, 2205-2233.

[7] Melan E., Parkus H.: Warmespannungen infolge stationarer temperaturfelder. Springer-Verlag, Wien 1953

[8] Novatsky V.: Problems of thermoelasticity. AS USSR Publishers, Moscow 1962.

[9] Oguamanam D.C.D., Hansen J.S., Heppler G.R.: Nonlinear transient response of thermally loaded laminated panels. J. Appl. Mech. Trans. ASME 71(1)/2004, 49-56.

[10] Ootao Y., Tanigawa Y.: Transient thermal stresses of angle-ply laminated cylindrical panel due to nonuniform heat supply in the circumferential direction. Compos. Structures 55(1)/2002, 95-103.

[11] Savoia M., Reddy J.N.: Three-dimensional thermal analysis of laminated composite plate. Int. J. Solids and Structures 32(5)/1995, 539-608.

[12] Shupikov A.N., Smetankina N.V., Svet Ye.V.: Nonstationary heat conduction in complex-shape laminated plates. J. Heat Transfer. Trans. ASME 129(3)/2007, 335-341.

[13] Smetankina N.V.: Non-stationary deformation, thermal elasticity and optimisation of laminated plates and cylindrical shells. Miskdruk Publishers, Kharkiv 2011.

[14] Tanigawa Y., Ootao Y., Kawamura R.: Thermal bending of laminated composite rectangular plates and nonhomogeneous plates due to partial heating. J. Thermal Stresses 14(3)/1991, 285-308.

[15] Verijenko V.E., Tauchert T.R., Shaikh C., Tabakov P.Y.: Refined theory of laminated anisotropic shells for the solution of thermal stress problems. J. Thermal Stresses 22(1)/1999, 75-100.

\section{D.Sc. Natalia Smetankina \\ e-mail:nsmetankina@ukr.net}

Head of the Department of Vibration and Thermostability Studies, A. Pidgorny Institute of Mechanical Engineering Problems, National Academy of Sciences of Ukraine. Scientific interests: mechanics of deformable solids, mathematical modeling, nonstationary vibrations, thermoelasticity, composites, impact, laminated structures.

http://orcid.org/0000-0001-9528-3741

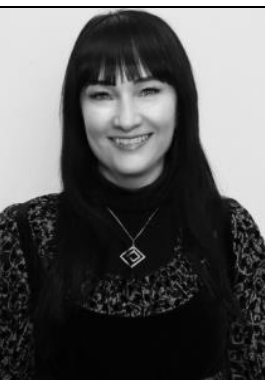

M.Sc. Oleksii Postnyi

e-mail: alekh.po@gmail.com

Post-graduate student at A. Pidgorny Institute of Mechanical Engineering Problems, National Academy of Sciences of Ukraine. Scientific interests: thermoelasticity, composites, laminated structures.

http://orcid.org/0000-0002-3151-3891

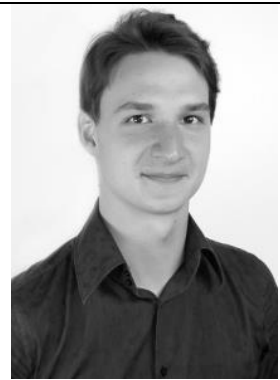

otrzymano/received: 22.12 .2019 